FOLIA POMERANAE UNIVERSITATIS TECHNOLOGIAE STETINENSIS

Folia Pomer. Univ. Technol. Stetin., Oeconomica 2018, 342(90)1, 17-28

Beata BĘDZIK, Sylwia GOŁĄB

\title{
ZAANGAŻOWANIE LOKALNEJ SPOKECZNOŚCI W SPRAWY GMINY. IMPLIKACJE DLA KAPITAŁU SPOŁECZNEGO
}

\author{
LOCAL COMMUNITY INVOLVEMENT IN THE COMMUNE AFFAIRS. \\ IMPLICATIONS FOR SOCIAL CAPITAL
}

Katedra Ekonomii i Rachunkowości, Zachodniopomorski Uniwersytet Technologiczny w Szczecinie ul. Żołnierska 47, 71-210 Szczecin, e-mail: beata.bedzik@zut.edu.pl, e-mail: sylwia.golab@zut.edu.pl

\begin{abstract}
Summary. The aim of paper is to present the level of respondents involvement in the commune affairs. The results of the analyzes presented in this paper come from surveys conducted using a questionnaire survey among residents of rural communes in the West Pomeranian Voivodeship. After rejecting incomplete and/or illogical questionnaires, 2409 respondents were qualified for the analysis. Verification of the existence of a relationship between the involvement in the commune affairs (social capital component) and the professional situation of the respondents was verified. The research results indicate the diversity of involvement in professional status groups. Analyzes shows that the respondents employed in the public sector and unemployed recorded a positive average level of involvement. The respondents employed in the private sector demonstrated a negative average level of involvement, which means they did not participate in activities for the benefit of the local community. The research results indicate the involvement is determined by the professional situation and determines the level of participation in the life of the commune. The relationship between social capital and commitment was the strongest by respondents working in the public sector, while the weakest by the unemployed.
\end{abstract}

Słowa kluczowe: kapitał społeczny, niepracujący, pracujący, rozwój społeczno-gospodarczy, status zawodowy, zaangażowanie.

Key words: commitment, employees, professional status, social capital, socio-economic development, unemployed.

\section{WSTĘP}

W dobie zaawansowanych procesów globalizacyjnych rozwój społeczno-gospodarczy nie jest możliwy do utrzymania dzięki wykorzystaniu dotychczasowych klasycznych czynników wzrostu, tj. pracy, ziemi i kapitału. Dotyczy to gospodarek wysokorozwiniętych, gdyż kraje słabiej rozwinięte nadal mogą czerpać korzyści z podnoszenia jakości chociażby kapitału ludzkiego. Wobec powyższego badacze w ostatnich dekadach zintensyfikowali wysiłki w celu zidentyfikowania potencjalnych generatorów rozwoju społeczno-gospodarczego. Wyniki badań międzynarodowych, przywołane przez Czapińskiego (2010), jednoznacznie wskazują na znaczenie kapitału społecznego w dalszym rozwoju wysokorozwiniętych gospodarek. Kraje słabiej rozwinięte mają jeszcze możliwości generowania wzrostu poprzez poprawę jakości tradycyjnych czynników, np. kapitału ludzkiego, natomiast gospodarki wysokorozwinięte 
osiągnęły już wystarczający poziom nasycenia tymi generatorami i do dalszego wzrostu potrzebują nowych rozwiązań. Na rycinie 1 zaprezentowano wyniki tych badań w odniesieniu do krajów bogatych i ubogich (odpowiednio 20 i 14 krajów), które jednoznacznie wskazują, że w krajach bogatych kapitał społeczny warunkuje wzrost PKB, zaś kapitał ludzki jest już stosunkowo mało istotny. Kapitał ludzki jest nadal ważny w krajach ubogich, w których z kolei kapitał społeczny nie ma znaczenia. W tym porównaniu Polskę zaliczono do grupy krajów ubogich, do rozwoju polskiej gospodarki zatem niezbędne było zwiększenie kapitału ludzkiego, choć Polska w okresie badań była o krok od osiągnięcia progu PKB per capita, po przekroczeniu którego spełniałaby przyjęte w przywołanych badaniach kryteria przynależności do grupy krajów bogatych. Jeśli weźmie się jednak pod uwagę sukcesywny wzrost gospodarczy, a także - co jest ważniejsze - długookresową perspektywę kreowania kapitału społecznego, wszelkie analizy przybliżające poziom i jakość kapitału społecznego w Polsce dają szansę na jego zwiększenie.

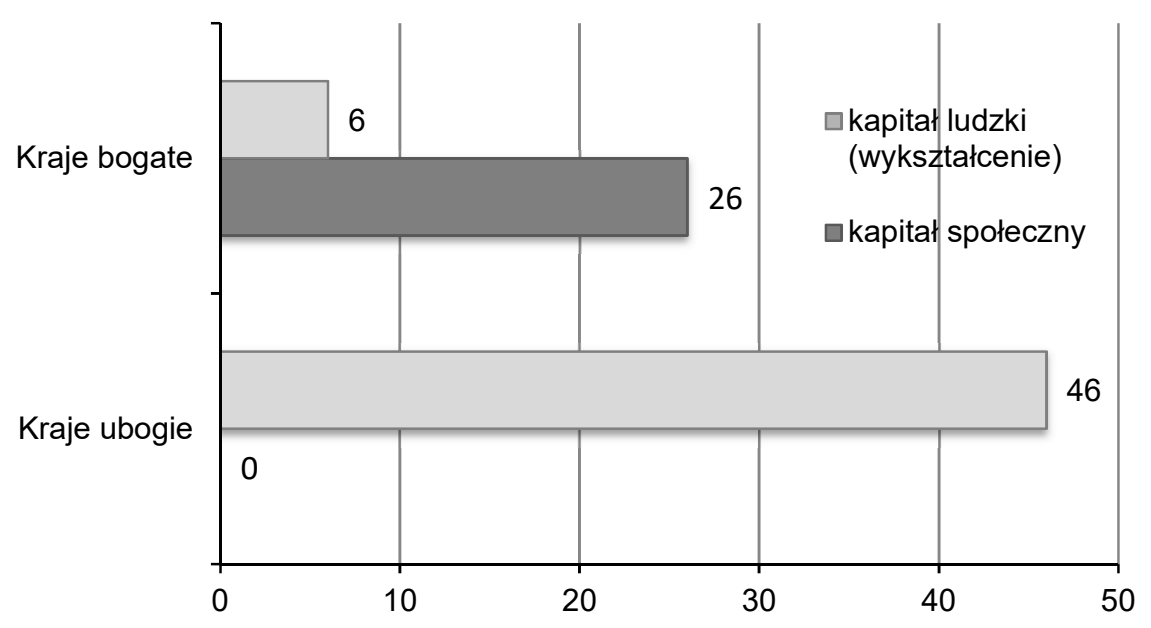

Ryc.1. Znaczenie kapitału ludzkiego (wykształcenie w 2000 r.) i pomostowego kapitału społecznego (zaufanie i kolektywizm instytucjonalny z drugiej połowy lat 90 . XX w.) w wyjaśnianiu logarytmu wzrostu PKB per capita w latach 1995-2006 w grupie 20 bogatych i 14 ubogich krajów. Procent wariancji wyjaśnionej przez dany kapitał przy kontroli pozostałego

Źródło: Bank Światowy, GLOBE i World Value Survey 2 i 3 fala za: Czapiński (2010).

Badacze kapitału społecznego w polskiej literaturze przedmiotu również wiele miejsca poświęcają wskazaniu zależności między kapitałem społecznym a rozwojem (m.in. Kenc 2015; Paczóski 2015; Kuchmacz 2016). Zaangażowanie lokalnej społeczności w sprawy gminy jako ważny komponent kapitału społecznego jest więc niezmiernie istotne w perspektywie długofalowego rozwoju. O roli współpracy i zaangażowania pisał już w XIX w. Alexis de Tocqueville w 1838 r., opisując upodobanie Amerykanów do stowarzyszania się w celu realizacji każdego niemal zadania. Na podobne czynniki przynoszące korzyści społeczności zwrócił uwagę po raz pierwszy, używając terminu „kapitał społeczny” we współczesnym jego rozumieniu, Lyda Hanifan (1916). Zdefiniował on kapitał społeczny przez pryzmat „[...] życzliwości, społeczności, wzajemnego współczucia i współżycia społecznego między grupą osób i rodzin tworzących jednostkę społeczną, społeczność wiejską [...]" (s. 130). Im więcej ludzie zrobią sami, tym większy kapitał społeczny zostanie wykreowany i tym większa 
będzie korzyść z inwestycji społecznych (Hanifan 1916). Wagę kapitału społecznego dostrzeżono w naukach ekonomicznych z uwagi na to, że „[...] kapitał społeczny uwidoczniony w relacjach między aktorami sceny lokalnej sprzyja współpracy i tworzeniu zaufania, co w konsekwencji może się przełożyć na rozwój lokalny" (Będzik 2008, s. 27). Wśród komponentów kapitału społecznego, oprócz zaufania i partycypacji obywatelskiej, wymienia się zaangażowanie, gdyż dzięki niemu możliwe jest „zmaterializowanie” korzyści płynących z budowania i pomnażania kapitału społecznego. Zaangażowanie społeczności lokalnych w Polsce jest niewystarczające, na co wskazują wyniki licznych w ostatnich latach badań. Z publikacji Instytutu Spraw Publicznych (Olech 2014) wyłania się obraz Polaków, którzy „[...] w niewielkim stopniu aktywnie uczestniczą w podejmowaniu decyzji dotyczących spraw publicznych w swoich gminach, nie korzystają także z możliwości bezpośrednich kontaktów z przedstawicielami władz lokalnych" (s. 2). Wyniki badań Niewiadomskiego (2015) także potwierdzają niski poziom zaangażowania w sprawy gminy, ograniczający się w większości przypadków do udziału w wyborach samorządowych.

Jak zauważa Olech (2014), „[...] zainteresowanie mieszkańców bezpośrednimi kontaktami z włodarzami gminy i ich aktywność rosną wówczas, gdy rozstrzygane są sprawy kontrowersyjne, związane najczęściej z planowanymi przez władze gminy inwestycjami lub w sytuacji referendum odwoławczego" (s. 14). Źródłem takiej postawy mogą być niewłaściwe relacje pomiędzy obywatelami a decydentami, co wyłania się z badań Niewiadomskiego (2015), który - analizując sumarycznie odpowiedzi respondentów na postawione pytania zauważył „[...] nie do końca poprawną komunikację na linii urząd-obywatel” (s. 74). Według niego poziom wiedzy na temat instytucji, z którymi mieszkańcy mogliby współpracować, jest również niewystarczający. Wnioskuje również, że obywatele nie są do końca przekonani o sensie działalności społecznej.

Badania z zakresu zaangażowania są istotne $z$ uwagi na ich powiązanie $z$ pozostałymi komponentami kapitału społecznego, a w konsekwencji również ze względu na ich przełożenie na przyszły rozwój społeczno-gospodarczy. Z raportu Stowarzyszenia Klon/Jawor (2014), odnoszącego się do całego kraju, wynika, że „[...] aktywność społeczna Polek i Polaków utrzymuje się od kilku lat na podobnym poziomie: aktywna jest około jedna trzecia społeczeństwa, przy czym w „formalny” wolontariat zaangażowanych było w 2013 roku 18\% (nieco więcej niż w latach poprzednich), a w działania na rzecz osób spoza kręgu rodziny i znajomych lub na rzecz okolicy $27 \%$ badanych (podobnie jak w latach poprzednich)" (s. 1). Dla poprawy dobrobytu jest to niezmiernie ważne, gdyż „[...] aktywność społeczna jest pozytywnie skorelowana $z$ działalnością filantropijną, podobnie jak z zaufaniem do obcych, wiarą w sens współpracy z innymi czy skłonnością do liczenia na pomoc innych" (Stowarzyszenie Klon/Jawor 2014, s. 107). Z raportów CBOS (Potencjał społecznikowski... 2016 i poprzednie lata), przeprowadzanych w odstępach dwuletnich, wynika, że odsetek osób deklarujących aktywność społeczną na rzecz swojego środowiska od kilkunastu lat kształtuje się na podobnym poziomie (ok. 59\% w 2016 r.), choć biorąc pod uwagę duży spadek (do poziomu 47\% w 2008 r.), należy mówić o tendencji wzrostowej (od tego czasu następuje systematyczny wzrost tego odsetka). Jeśli chodzi o sytuację zawodową respondentów, w ww. badaniach tego typu działania częściej podejmuje kadra kierownicza i specjaliści wyższego szczebla, rolnicy, prywatni przedsiębiorcy oraz uczniowie i studenci. 
Zdaniem Rycharda (2015) należy włożyć wiele wysiłku w rozwój aktywności i współpracy ze względu na ich istotność w budowaniu kapitału społecznego. Badania lokalne są niezmiernie ważne z uwagi na polską specyfikę, w której przejawy kapitału społecznego i poszczególnych jego komponentów są wyraźniejsze w lokalnej rzeczywistości niż w ujęciu statystyki ogólnokrajowej. „Nie zwalnia to jednak z dalszych prób pobudzania społeczności do włączania się w sprawy gminy, ponieważ budowa kapitału społecznego to proces długofalowy i trudny, gdyż obarczony negatywnymi doświadczeniami gospodarki opartej wprawdzie na wspólnej własności, lecz zupełnie inaczej skonfigurowanej" (Będzik 2016, s. 120).

Celem pracy jest ocena poziomu zaangażowania w sprawy gminy mieszkańców zachodniopomorskich gmin wiejskich i ewentualne implikacje dla przyszłego kapitału społecznego.

\section{MATERIAt I METODA}

Kapitał społeczny jest kreowany na płaszczyźnie zaufania, współpracy, partycypacji itp.; są to komponenty, które najsilniej ujawniają się i oddziałują w najbliższym otoczeniu. Jednocześnie ich natężenie słabnie wraz ze wzrostem zasięgu. Generuje to więc dobór narzędzi pomiaru, który powinien ograniczać się do szczebla lokalnego. W związku z powyższym niniejszy artykuł koncentruje się na ocenie poziomu zaangażowania w sprawy gminy lokalnej społeczności z gmin wiejskich województwa zachodniopomorskiego i na zbadaniu, czy sytuacja zawodowa mieszkańców warunkuje stopień tego zaangażowania.

Wyniki analiz zaprezentowanych w niniejszej pracy pochodzą z badań przeprowadzonych w 2012 i 2013 roku, z wykorzystaniem kwestionariusza ankiety, wśród mieszkańców gmin wiejskich województwa zachodniopomorskiego. Po odrzuceniu niepełnych i/lub nielogicznych ankiet do analiz zakwalifikowano 2409 respondentów. Większość badanych $(57,95 \%)$ stanowiły kobiety. Prawie połowa respondentów nie przekroczyła 30 roku życia.

$Z$ uwagi na ograniczone ramy niniejszej publikacji rozpatrywano wyłącznie zaangażowanie w sprawy gminy i odnoszono je do kapitału społecznego. Zaangażowanie w sprawy gminy analizowano na podstawie członkostwa w organizacjach pozarządowych, podejmowania prób zrobienia czegoś dla gminy oraz działalności na rzecz lokalnej społeczności, przy czym respondent mógł działać dla realizacji wspólnych celów jako inicjator, główny realizator przedsięwzięcia lub czynny, lub bierny jego uczestnik.

W opracowaniu zostały użyte następujące statystyki opisowe:

- do zmierzenia zależności pomiędzy wybranymi zmiennymi wykorzystano test niezależności chi-kwadrat Pearsona $\left(x^{2}\right)$ - najodpowiedniejszy do badania zależności między zmiennymi o charakterze jakościowym;

- do oszacowania modeli z jedną oraz więcej niż jedną zmiennymi objaśniającymi wykorzystano regresję wieloraką, najodpowiedniejszą do ilościowego ujęcia związków pomiędzy wieloma zmiennymi niezależnymi (objaśniającymi) a zmienną zależną (kryterialną, objaśnianą).

\section{WYNIKI}

\section{Aktywność w działalności lokalnej}

Zaangażowanie w sprawy gminy przeanalizowano w trzech wymiarach, tj. w wymiarze przynależności do organizacji społecznej, podejmowania prób zrobienia czegoś dla gminy 
oraz sprawdzając charakter uczestnictwa w działalności na rzecz lokalnej społeczności. Analizy przeprowadzono z uwzględnieniem statusu zawodowego badanych.

Większość badanych nie należała do żadnej organizacji społecznej (tab. 1), przy czym największy odsetek takich wskazań dotyczył osób pracujących w sektorze prywatnym u kogoś (96,29\%), zaś najmniejszy - osób pracujących w sektorze publicznym $(59,74 \%)$. Ważne jest to, że wśród osób pracujących w sektorze publicznym znacznie więcej osób należało do jakiejś organizacji społecznej (10,82\%) niż w pozostałych grupach (odpowiednio od 0,43\% do $2,96 \%)$. Wyniki testu chi-kwadrat wskazują, iż zachodziła istotna statystycznie zależność między sytuacją zawodową a przynależnością do organizacji społecznej $(p<0,001)$.

Tabela 1. Przynależność do organizacji społecznej z uwzględnieniem sytuacji zawodowej badanych [\%]

\begin{tabular}{|c|c|c|c|c|c|}
\hline Odpowiedzi & $\begin{array}{l}\text { Pracujący } \\
\text { w sektorze } \\
\text { publicznym }\end{array}$ & $\begin{array}{l}\text { Pracujący } \\
\text { w sektorze } \\
\text { prywatnym } \\
\text { u kogoś }\end{array}$ & $\begin{array}{c}\text { Pracujący w sektorze } \\
\text { prywatnym } \\
\text { (własna działalność } \\
\text { gospodarcza) }\end{array}$ & Niepracujący & $\begin{array}{l}\text { Wyniki testu } \\
\text { chi-kwadrat }\end{array}$ \\
\hline Tak & 10,82 & 0,43 & 0,75 & 2,96 & \multirow{4}{*}{$\begin{array}{c}X^{2}=436,897 \\
d f=6 \\
p=0,000\end{array}$} \\
\hline Nie & 59,74 & 96,29 & 89,00 & 65,19 & \\
\hline Nie wiem & 29,44 & 3,29 & 10,25 & 31,85 & \\
\hline Ogółem & 100,00 & 100,00 & 100,00 & 100,00 & \\
\hline
\end{tabular}

Większość badanych z grup pracujących w sektorze publicznym i niepracujących podejmowała próby zrobienia czegoś dla gminy (odpowiednio 73,16\% i 48,89\%) - tab. 2 . W przypadku osób pracujących w sektorze prywatnym u kogoś większość $(62,26 \%)$ nie podejmowała nigdy takich prób. Z kolei badani prowadzący własną działalność gospodarczą byli najbardziej pod tym względem podzieleni, z czego najczęściej $(39,00 \%)$ nie byli w stanie jednoznacznie określić, czy podejmowali takie próby; nieco mniej badanych z tej grupy $(34,50 \%)$ wskazało, iż nie miało to miejsca. Wyniki testu chi-kwadrat wskazują, iż zachodziła istotna statystycznie zależność między sytuacją zawodową a podejmowaniem prób zrobienia czegoś dla gminy $(p<0,001)$.

Tabela 2. Podejmowanie prób zrobienia czegoś dla gminy w zależności od sytuacji zawodowej badanych [\%]

\begin{tabular}{|c|c|c|c|c|c|}
\hline Odpowiedzi & $\begin{array}{l}\text { Pracujący } \\
\text { w sektorze } \\
\text { publicznym }\end{array}$ & $\begin{array}{l}\text { Pracujący } \\
\text { w sektorze } \\
\text { prywatnym } \\
\text { u kogoś }\end{array}$ & $\begin{array}{c}\text { Pracujący w sektorze } \\
\text { prywatnym } \\
\text { (własna działalność } \\
\text { gospodarcza) }\end{array}$ & Niepracujący & $\begin{array}{l}\text { Wyniki testu } \\
\text { chi-kwadrat }\end{array}$ \\
\hline Tak & 73,16 & 15,09 & 26,50 & 48,89 & \multirow{4}{*}{$\begin{array}{c}X^{2}=511,88 \\
d f=6 \\
p=0,000\end{array}$} \\
\hline $\mathrm{Nie}$ & 26,84 & 62,26 & 34,50 & 40,74 & \\
\hline $\begin{array}{l}\text { Nie wiem/ trudno } \\
\text { powiedzieć }\end{array}$ & 0,00 & 22,64 & 39,00 & 10,37 & \\
\hline Ogółem & 100,00 & 100,00 & 100,00 & 100,00 & \\
\hline
\end{tabular}

Badani pracujący w sektorze publicznym oraz niepracujący, jeżeli podejmowali działania na rzecz lokalnej społeczności, to najczęściej byli czynnymi uczestnikami (odpowiednio $45,89 \%$ i $53,33 \%$ ) - tab. 3 . Z grupy osób pracujących w sektorze prywatnym u kogoś prawie 
połowa osób $(47,66 \%)$ była biernymi uczestnikami. Z kolei badani prowadzący własną działalność gospodarczą najczęściej (co druga osoba; 50,50\%) nie byli w stanie jednoznacznie określić swojej roli. Oznacza to, że aktywnie w przedsięwzięciach uczestniczyli jedynie respondenci pracujący $w$ sektorze publicznym oraz niepracujący, natomiast ankietowani z pozostałych grup, jeżeli w ogóle uczestniczyli w jakichkolwiek działaniach, to raczej w roli biernych uczestników (ok. 48\% pracujących w sektorze prywatnym u kogoś i ponad $21 \%$ prowadzących własną działalność). Wyniki testu chi-kwadrat wskazują, iż zachodziła istotna statystycznie zależność między sytuacją zawodową a rolą w działalności na rzecz lokalnej społeczności $(p<0,001)$.

Tabela 3. Rola w działalności na rzecz lokalnej społeczności w zależności od sytuacji zawodowej badanych [\%]

\begin{tabular}{|c|c|c|c|c|c|}
\hline Odpowiedzi & $\begin{array}{c}\text { Pracujący } \\
\text { w sektorze } \\
\text { publicznym }\end{array}$ & $\begin{array}{l}\text { Pracujący } \\
\text { w sektorze } \\
\text { prywatnym } \\
\text { u kogoś }\end{array}$ & $\begin{array}{c}\text { Pracujący w sektorze } \\
\text { prywatnym } \\
\text { (własna działalność } \\
\text { gospodarcza) }\end{array}$ & Niepracujący & $\begin{array}{l}\text { Wyniki testu } \\
\text { chi-kwadrat }\end{array}$ \\
\hline $\begin{array}{l}\text { Jako inicjator } \\
\text { przedsięwzięcia }\end{array}$ & 3,03 & 5,90 & 4,50 & 5,93 & \multirow{6}{*}{$\begin{array}{c}X^{2}=479,379 \\
d f=12 \\
p=0,000\end{array}$} \\
\hline $\begin{array}{l}\text { Jako główny } \\
\text { realizator } \\
\text { przedsięwzięcia }\end{array}$ & 19,91 & 5,36 & 6,25 & 16,30 & \\
\hline $\begin{array}{l}\text { Jako czynny } \\
\text { uczestnik }\end{array}$ & 45,89 & 18,99 & 17,25 & 53,33 & \\
\hline $\begin{array}{l}\text { Jako bierny } \\
\text { uczestnik }\end{array}$ & 6,49 & 47,66 & 21,50 & 0,74 & \\
\hline Trudno powiedzieć & 24,68 & 22,09 & 50,50 & 23,70 & \\
\hline Ogółem & 100,00 & 100,00 & 100,00 & 100,00 & \\
\hline
\end{tabular}

\section{Kapitał społeczny w grupach zróżnicowanych pod względem sytuacji zawodowej - analiza wariancji}

Wyniki najważniejszych zmiennych (partycypacji, zaufania i zaangażowania oraz kapitału społecznego jako sumy ww. elementów) porównano w grupach zróżnicowanych pod względem sytuacji zawodowej. W tym celu zbadano istotność różnic w poszczególnych wynikach między badanymi w różnej sytuacji zawodowej, tj. pracującymi w sektorze publicznym, prywatnym u kogoś, prywatnym (własna działalność gospodarcza) i niepracującymi. W tabeli 4 przedstawiono wyniki badań istotności różnic.

Tabela 4. Badanie istotności różnic $w$ kapitale społecznym między grupami zróżnicowanymi pod względem sytuacji zawodowej (wyniki analizy wariancji)

\begin{tabular}{|l|r|r|r|r|r|r|r|r|}
\hline \multirow{2}{*}{ Zmienna } & \multicolumn{9}{|c|}{ Analiza wariancji* } \\
\cline { 2 - 9 } & $\begin{array}{c}\text { SS } \\
\text { efekt }\end{array}$ & $\begin{array}{c}d f \\
\text { efekt }\end{array}$ & $\begin{array}{c}\text { MS } \\
\text { efekt }\end{array}$ & $\begin{array}{c}\text { SS } \\
\text { błąd }\end{array}$ & $\begin{array}{c}d f \\
\text { błąd }\end{array}$ & $\begin{array}{c}\text { MS } \\
\text { błąd }\end{array}$ & $F$ & $p$ \\
\hline Partycypacja & 108,80 & 3 & 36,266 & 1574,92 & 2409 & 0,65485 & 55,3808 & 0,00 \\
\hline Zaufanie & 6905,85 & 3 & 2301,949 & 37786,30 & 2409 & 15,71156 & 146,5131 & 0,00 \\
\hline Zaangażowanie & 888,09 & 3 & 296,031 & 7153,54 & 2409 & 2,97445 & 99,5248 & 0,00 \\
\hline Kapitał społeczny & 12026,79 & 3 & 4008,930 & 70893,31 & 2409 & 29,47747 & 135,9998 & 0,00 \\
\hline
\end{tabular}

*Zaznaczone efekty są istotne $\mathrm{z} p<, 05000$.

$S S$ - suma kwadratów badanego efektu oraz błędu, $d f$ - międzygrupowe i wewnątrzgrupowe stopnie swobody, $M S$ - średnia suma kwadratów efektu i błędu, $F$ - wartość statystyki, $p$ - prawdopodobieństwo testowe. 
Badanie istotności różnic potwierdziło, że ankietowani pogrupowani według sytuacji zawodowej różnili się między sobą istotnie statystycznie pod względem zarówno kapitału społecznego ( $p<0,001)$, jak i każdego jego elementu z osobna $(p<0,001)$. W każdym badanym przypadku zanotowano istotne statystycznie różnice między poszczególnymi grupami. Z uwagi na objętość publikacji na ryc. 2 zaprezentowano wyłącznie podstawowe statystyki opisowe dotyczące zaangażowania w sprawy gminy, zanotowane w grupach zróżnicowanych pod względem sytuacji zawodowej. Ich analiza pozwoliła zweryfikować różnice między poszczególnymi grupami, które - jak wykazała analiza wariacji - są istotne statystycznie.

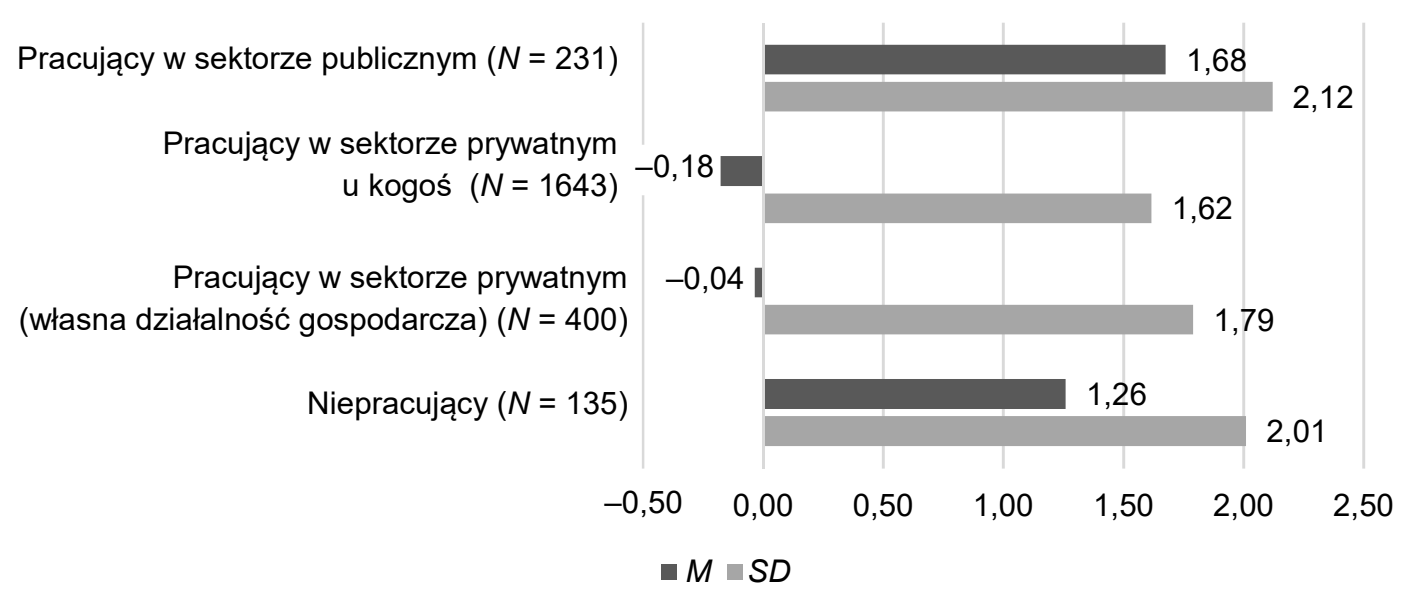

Ryc. 2. Poziom zaangażowania w sprawy gminy w zależności od sytuacji zawodowej badanych (podstawowe statystyki opisowe). $M$ - średnia, $S D$ - odchylenie standardowe

Pod względem poziomu zaangażowania w sprawy gminy badanych w różnej sytuacji zawodowej można podzielić na dwie grupy: 1) pracujących w sektorze publicznym i niepracujących, 2) pracujących w sektorze prywatnym - zarówno u kogoś, jak i prowadzących działalność gospodarczą. W przypadku badanych pracujących w sektorze publicznym i niepracujących odnotowano dodatni średni poziom zaangażowania, wynoszący odpowiednio 1,68 (przy odchyleniu standardowym 2,12) i 1,26 (przy odchyleniu standardowym 2,01). Z kolei w przypadku badanych pracujących w sektorze prywatnym, zarówno u kogoś, jak i prowadzących własną działalność gospodarczą, odnotowano ujemny średni poziom zaangażowania, wynoszący odpowiednio $-0,18$ (przy odchyleniu standardowym 1,62 ) i $-0,04$ (przy odchyleniu standardowym 1,79).

\section{Zaangażowanie w sprawy gminy według sytuacji zawodowej i jego implikacje dla kapitału społecznego}

$\mathrm{Na}$ potrzeby niniejszych badań opracowano model regresji dla kapitału społecznego, uwzględniając jedną zmienną niezależną, jaką było zaangażowanie w sprawy gminy. Wyniki tych analiz w zależności od sytuacji zawodowej ankietowanych zaprezentowano w tab. 5-8. 
Tabela 5. Wyniki regresji kapitału społecznego dla zmiennej: zaangażowanie w sprawy gminy w grupie osób pracujących w sektorze publicznym $(N=231)$

\begin{tabular}{|l|r|r|r|r|r|c|}
\hline Wyszczególnienie & $\begin{array}{c}\text { Współczynnik } \\
b^{*}\end{array}$ & $\begin{array}{c}\text { Błąd } \\
\text { standardowy } \\
z b^{*}\end{array}$ & $\begin{array}{c}\text { Współczynnik } \\
b\end{array}$ & $\begin{array}{c}\text { Błąd } \\
\text { standardowy } \\
z b\end{array}$ & $t(229)$ & Wartość $p$ \\
\hline Wyraz wolny & & & $-0,825087$ & 0,235726 & $-3,50019$ & 0,000559 \\
\hline Zaangażowanie & 0,812797 & 0,038496 & 1,843915 & 0,087332 & 21,11391 & 0,00 \\
\hline
\end{tabular}

$R=0,81279690, R^{2}=0,66063880$, poprawione $R^{2}=0,65915688, F(1,229)=445,80$, wartość $p<0,0000$, błąd standardowy estymacji: 2,8091 .

Wyniki regresji zmiennej zależnej pozwoliły oszacować następujący model dla grupy osób pracujących w sektorze publicznym:

$$
\text { kapitał społeczny }=-0,8251+1,8439 \cdot \text { zaangażowanie }
$$

Zgodnie z tak oszacowanym modelem, jeśli zmienna objaśniająca, tj. zaangażowanie, przyjmuje wartość zero, to zmienna objaśniana (tj. kapitał społeczny) przeciętnie przyjmuje wartość około $-0,8251$. Wzrost zaangażowania o jednostkę oznacza, że zmienna objaśniana (tj. kapitał społeczny) przeciętnie przyjmuje wartość wynoszącą już około 1,0188 $(-0,8251+1,8439 \cdot 1)$. Model jest dobry, ponieważ wyjaśnia 66,06\% zmienności kapitału społecznego.

Tabela 6. Wyniki regresji kapitału społecznego dla zmiennej: zaangażowanie w sprawy gminy w grupie osób pracujących w sektorze prywatnym u kogoś $(N=1643)$

\begin{tabular}{|l|c|c|c|c|c|c|}
\hline Wyszczególnienie & $\begin{array}{c}\text { Współczynnik } \\
b^{*}\end{array}$ & $\begin{array}{c}\text { Błąd } \\
\text { standardowy } \\
\mathbf{z} b^{*}\end{array}$ & $\begin{array}{c}\text { Współczynnik } \\
b\end{array}$ & $\begin{array}{c}\text { Błąd } \\
\text { standardowy } \\
z b\end{array}$ & $t(1641)$ & Wartość $p$ \\
\hline Wyraz wolny & & & $-3,36856$ & 0,077291 & $-43,5829$ & 0,00 \\
\hline Zaangażowanie & 0,777989 & 0,015509 & 2,38302 & 0,047506 & 50,1621 & 0,00 \\
\hline
\end{tabular}

$R=0,77798866, R^{2}=0,60526635$, poprawione $R^{2}=0,60502581, F(1,1641)=2516,2$, wartość $p<0,0000$, błąd standardowy estymacji: 3,1143 .

Dla grupy osób pracujących w sektorze prywatnym u kogoś wyniki regresji zmiennej zależnej (tab. 6) pozwoliły oszacować następujący model:

kapitał społeczny $=-3,3686+2,3830 \cdot$ zaangażowanie

Zgodnie z tak oszacowanym modelem, jeśli zmienna objaśniająca, tj. zaangażowanie, przyjmuje wartość zero, to zmienna objaśniana (tj. kapitał społeczny) przeciętnie przyjmuje wartość około $-3,3686$. Wzrost zaangażowania o jednostkę oznacza, że zmienna objaśniana (tj. kapitał społeczny) przeciętnie przyjmuje wartość wynoszącą już około -0,9856 (-3,3686 + $+2,3830$ - 1). Model jest dobry, ponieważ wyjaśnia 60,53\% zmienności kapitału społecznego. 
Tabela 7. Wyniki regresji kapitału społecznego dla zmiennej: zaangażowanie w grupie osób pracujących w sektorze prywatnym (własna działalność gospodarcza) $(N=400)$

\begin{tabular}{|l|c|c|c|c|c|c|}
\hline Wyszczególnienie & $\begin{array}{c}\text { Współczynnik } \\
b^{*}\end{array}$ & $\begin{array}{c}\text { Błąd } \\
\text { standardowy } \\
\mathbf{z} b^{*}\end{array}$ & $\begin{array}{c}\text { Współczynnik } \\
b\end{array}$ & $\begin{array}{c}\text { Błąd } \\
\text { standardowy } \\
z b\end{array}$ & $t(398)$ & Wartość $p$ \\
\hline Wyraz wolny & & & $-5,60036$ & 0,227522 & $-24,6145$ & 0,00 \\
\hline Zaangażowanie & 0,790541 & 0,030697 & 3,27546 & 0,127189 & 25,7527 & 0,00 \\
\hline
\end{tabular}

$R=0,79054052, R^{2}=0,62495432$, poprawione $R^{2}=0,62401199, F(1,398)=663,20$, wartość $p<0,0000$, błąd standardowy estymacji: 4,5496 .

Dla grupy osób pracujących w sektorze prywatnym prowadzących własną działalność gospodarczą wyniki regresji zmiennej (tab. 7) zależnej pozwoliły oszacować następujący model:

kapitał społeczny $=-5,6004+3,2755 \cdot$ zaangażowanie

Zgodnie z tak oszacowanym modelem, jeśli zmienna objaśniająca, tj. zaangażowanie, przyjmuje wartość zero, to zmienna objaśniana (tj. kapitał społeczny) przeciętnie przyjmuje wartość około -5,6004. Wzrost zaangażowania o jednostkę oznacza, że zmienna objaśniana (tj. kapitał społeczny) przeciętnie przyjmuje wartość wynoszącą już około -2,3249 (-5,6004 + $+3,2755 \cdot 1)$. Model jest dobry, ponieważ wyjaśnia 62,49\% zmienności kapitału społecznego.

Tabela 8. Wyniki regresji kapitału społecznego dla zmiennej: zaangażowanie w grupie osób niepracujących $(N=135)$

\begin{tabular}{|l|c|c|c|c|c|c|}
\hline Wyszczególnienie & $\begin{array}{c}\text { Współczynnik } \\
b^{*}\end{array}$ & $\begin{array}{c}\text { Błąd } \\
\text { standardowy } \\
\mathbf{z} b^{*}\end{array}$ & $\begin{array}{c}\text { Współczynnik } \\
b\end{array}$ & $\begin{array}{c}\text { Błąd } \\
\text { standardowy } \\
z b\end{array}$ & $t(133)$ & Wartość $p$ \\
\hline Wyraz wolny & & & $-1,66706$ & 0,328161 & $-5,08000$ & 0,000001 \\
\hline Zaangażowanie & 0,760133 & 0,056342 & 1,87090 & 0,138674 & 13,49140 & 0,00 \\
\hline
\end{tabular}

$R=0,76013262, R^{2}=0,57780159$, poprawione $R^{2}=0,57462717, F(1,133)=182,02$, wartość $p<0,0000$, błąd standardowy estymacji: 3,2282.

Natomiast dla grupy osób niepracujących wyniki regresji zmiennej zależnej (tab. 8) pozwoliły oszacować następujący model:

kapitał społeczny $=-1,6671+1,8709 \cdot$ zaangażowanie

Zgodnie z tak oszacowanym modelem, jeśli zmienna objaśniająca, tj. zaangażowanie, w sprawy gminy przyjmuje wartość zero, to zmienna objaśniana, czyli kapitał społeczny przeciętnie przyjmuje wartość około $-1,6671$. Wzrost zaangażowania o jednostkę oznacza, że zmienna objaśniana (tj. kapitał społeczny) przeciętnie przyjmuje wartość wynoszącą już około $0,2038(-1,6671+1,8709 \cdot 1)$. Model jest umiarkowanie dobry, ponieważ wyjaśnia $57,78 \%$ zmienności kapitału społecznego.

Przedstawione wyżej modele wskazują, że analizowana zależność między kapitałem społecznym a zaangażowaniem w sprawy gminy była najsilniejsza wśród badanych pracujących w sektorze publicznym (współczynnik determinacji kształtował się na najwyższym poziomie i wyniósł 0,6606). Rycina 3 obrazuje opracowany model, wskazując zależność kapitału społecznego od zaangażowania w sprawy gminy w grupach zróżnicowanych pod względem sytuacji zawodowej. 


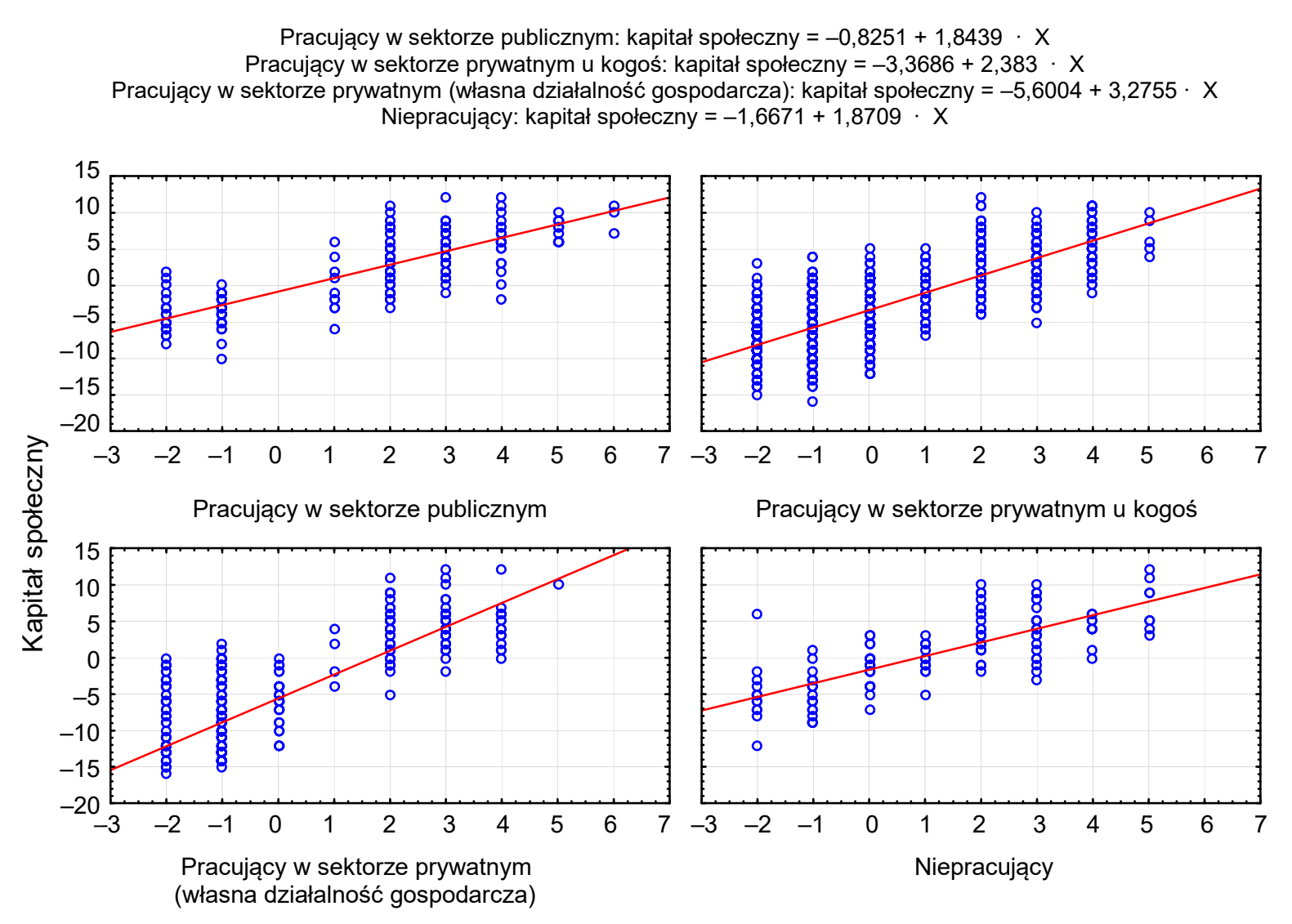

Zaangażowanie

Ryc. 3. Rozrzut między zaangażowaniem a kapitałem społecznym w grupach zróżnicowanych pod względem sytuacji zawodowej

\section{PODSUMOWANIE}

Kapitał społeczny jest kategorią zakorzenioną w lokalnej społeczności, nie ma zatem charakteru uniwersalnego i uwarunkowany jest lokalną specyfiką. Dlatego badania, których przedmiotem jest kapitał społeczny lub jego komponenty, powinny być ograniczone lokalnie. W niniejszym opracowaniu zaprezentowano wyniki badań kapitału społecznego w gminach wiejskich województwa zachodniopomorskiego, koncentrując się na zaangażowaniu lokalnej społeczności w sprawy gminy. Ten aspekt kapitału społecznego wydaje się istotny dla uwidocznienia efektów posiadanego kapitału, który nie zostanie wykorzystany, jeśli mieszkańcy nie będą aktywnie uczestniczyć w życiu gminy. Wyniki analiz potwierdziły zależność między kapitałem społecznym a zaangażowaniem w sprawy gminy, przy czym zależność ta była najsilniejsza wśród badanych pracujących w sektorze publicznym, najsłabsza zaś wśród niepracujących.

Wyniki badań potwierdzają niski poziom zaangażowania mieszkańców zachodniopomorskich obszarów wiejskich, który często przyjmował wartości ujemne i który wykazywał zróżnicowanie ze względu na sytuację zawodową ankietowanych. Analizy wykazały, że badani pracujący w sektorze publicznym oraz niepracujący odnotowali dodatni średni poziom zaangażowania. Ponad $73 \%$ pracujących w sektorze publicznym i prawie połowa niepracujących podejmowała próby zrobienia czegoś dla gminy. Z kolei badani pracujący w sektorze prywatnym, zarówno u kogoś, jak i prowadzący własną działalność gospodarczą, wskazywali ujemny średni 
poziom zaangażowania, co oznacza, że raczej nie angażowali się w działalność na rzecz lokalnej społeczności. Wyniki dotyczące roli w podejmowanych inicjatywach również wskazują na relatywnie większe zaangażowanie w sprawy gminy pracujących w sektorze publicznym oraz niepracujących. Prawie jedna czwarta ankietowanych z tych grup angażowała się w działalność jako główny realizator lub inicjator przedsięwzięcia, podczas gdy w pozostałych grupach odsetek ten oscylował wokół 11\%. Dodatkowo w podejmowanych działaniach czynnie uczestniczyli pracujący w sektorze publicznym (prawie 46\% wskazań) oraz niepracujący (ponad 53\% wskazań). Przynależność do organizacji społecznej zadeklarował jedynie co dziesiąty respondent pracujący w sektorze publicznym, przy czym w pozostałych grupach zawodowych ten odsetek był nieznaczny i poza niepracującymi $(2,96 \%)$ nie przekroczył $1 \%$.

Analizy potwierdziły, że zaangażowanie w sprawy gminy jest zdeterminowane sytuacją zawodową, w jakiej znajdują się mieszkańcy danej gminy i w dużym stopniu warunkuje poziom uczestnictwa w życiu gminy. W raporcie podsumowującym badania pt. „Budowa kapitału społecznego do wykorzystania w procesie zarządzania rozwojem kierowanym przez lokalną społeczność" (Thlon 2015) na pierwszym miejscu, w części dotyczącej wniosków, zapisano: „Aktywizacja społeczności lokalnych jest jednym z najistotniejszych zjawisk decydujących o charakterze i przyszłości obszarów wiejskich” (s. 107). W odniesieniu do wyników badań zaprezentowanych w niniejszej pracy, której konkluzje wskazują na niski poziom zaangażowania mieszkańców zachodniopomorskich gmin wiejskich, należy stwierdzić, że pobudzanie aktywności społeczności lokalnej powinno być priorytetem we wszystkich programach strategicznych tworzonych przez władze samorządowe.

\section{PIŚMIENNICTWO}

Aktywność społeczna Polaków. 2014. Komunikat z badań CBOS. Warszawa, 1-13.

Będzik B. 2008. Kapitał społeczny jako ważny czynnik rozwoju lokalnego. Problemy rozwoju polityki regionalnej i lokalnej. Zadania, uwarunkowania, dylematy rozwoju regionów. Szczecin, Economicus, 25-32.

Będzik B. 2016. Aktywność czy bierność na obszarach wiejskich w województwie zachodniopomorskim. Europa Reg. 27, 111-121.

Czapiński J. 2010. Kapitał społeczny jako motor rozwoju rozwiniętych. Małopol. Stud. Reg. 1(18), 29-38.

Tocqueville A. 1976. O demokracji w Ameryce. Tłum. M. Król. Warszawa, PIW, 334.

Hanifan L.J. 1916. The rural school community center. The Ann. Am. Acad. Polit. Soc. Sc. 67, 130-138.

Kenc J. 2015. Kapitał społeczny i jego rola w rozwoju lokalnym. Współczesne problemy Ekonomiczne. Zesz. Nauk. USzczec., Współczesne Problemy Ekonomiczne. Globalizacja. Liberalizacja. Etyka 851, 147-156.

Kuchmacz B. 2016. Kapitał społeczny jako czynnik rozwoju lokalnego. Warszawa, CeDeWu, 1-266.

Niewiadomski K. 2015. Zaangażowanie społeczności lokalnej w zarządzaniu gminą. Zesz. Nauk. PCzęst., Zarządzanie 20, 67-76.

Olech A. 2014. Między zainteresowaniem a zaangażowaniem - aktywność obywatelska i organizacje pozarządowe w Polsce. Analizy i Opinie ISP Warsz. 7, 2-15.

Paczóski P. 2015. Znaczenie i wpływ kapitału społecznego na rozwój lokalny. Pr. Nauk. UE Wroc. 391, 229-238. 
Potencjał społecznikowski oraz zaangażowanie w pracę społeczną. Komunikat z badań. 2016. Warszawa, CBOS, 14-19.

Rychard A. 2015. Bardziej uspołecznieni niż to się wydaje? w: Jak lokalnie budować partnerstwa. Warszawa, Chromapress Sp. z o.o., 30-47.

Thlon M., Piotrowski M., Bański J., Zarudzki R., Idziak W., Bukowski A. 2015. Budowa kapitału społecznego do wykorzystania $w$ procesie zarządzania rozwojem kierowanym przez lokalną społeczność. Raport podsumowujący. Warszawa, CDR w Brwinowie, 100-108.

Zaangażowanie społeczne Polek i Polaków. Wolontariat, filantropia, 1\% i wizerunek organizacji pozarządowych. Raport z badania 2013. 2014. Warszawa, Stowarzyszenie Klon/Jawor, 1-109.

Streszczenie. Celem pracy jest zaprezentowanie poziomu zaangażowania w sprawy gminy lokalnej społeczności. Wyniki analiz pochodzą z badań przeprowadzonych przy wykorzystaniu kwestionariusza ankiety wśród respondentów z gmin wiejskich województwa zachodniopomorskiego. Po odrzuceniu niekompletnych i/lub nielogicznych ankiet do dalszych analiz zakwalifikowano 2409 respondentów. Poddano weryfikacji istnienie zależności między zaangażowaniem w sprawy gminy (komponent kapitału społecznego) a sytuacją zawodową respondentów. Wyniki badań przedstawiają niski poziom zaangażowania mieszkańców zachodniopomorskich obszarów wiejskich, który był zróżnicowany ze względu na sytuację zawodową ankietowanych. Analizy wykazały dodatni średni poziom zaangażowania badanych pracujących w sektorze publicznym i niepracujących, a ujemny średni poziom zaangażowania badanych pracujących w sektorze prywatnym, co oznacza, że raczej nie uczestniczyli oni w działalności na rzecz lokalnej społeczności. Dalsze analizy potwierdziły, że zaangażowanie w sprawy gminy jest zdeterminowane sytuacją zawodową i że $w$ dużym stopniu warunkuje poziom uczestnictwa w życiu gminy. Zależność między kapitałem społecznym a zaangażowaniem była najsilniejsza wśród badanych pracujących w sektorze publicznym, najsłabsza zaś wśród niepracujących. 